\title{
Between citizenship and the millet: the Greek minority in republican Turkey
}

\section{loannis N. Grigoriadis}

To cite this article: Ioannis N. Grigoriadis (2021) Between citizenship and the millet: the Greek minority in republican Turkey, Middle Eastern Studies, 57:5, 741-757, DOI: 10.1080/00263206.2021.1894553

To link to this article: https://doi.org/10.1080/00263206.2021.1894553

\section{Published online: 01 Apr 2021.}

Submit your article to this journal $₫$

Џll Article views: 373

Q View related articles $\asymp$

View Crossmark data ¿ 


\title{
Between citizenship and the millet: the Greek minority in republican Turkey
}

\author{
loannis N. Grigoriadis
}

Department of Political Science and Public Administration, Bilkent University, Ankara, Turkey

Turkey's Greek minority is one of the three minorities officially recognized in the Treaty of Lausanne, the founding document of republican Turkey. Despite the protective treaty provisions, it suffered persistent discrimination throughout the republican era due to state suspicion against all minority groups, souring Greek-Turkish relations and the Cyprus question. This led to the sharp decline of the demographic size of the minority from about 125,000 persons in the mid-1920s to about 2,500 persons in the late 1990s. Nevertheless, Turkey's political reform initiated in the early 2000s opened a window of opportunity for the survival of the minority. Several measures restituting minority individuals and institutions to their rights and assets were taken.

This study embarks on an overview of the history of Turkey's Greek minority. It then explores the state of Turkey's Greek minority since 2002 by focusing on three critical questions: the minority pious foundations (vakıf), the Papa Eftim affair and the Gökçeada (Imbros) and Bozcaada (Tenedos) Greeks. In doing that, it aims to answer the question why the Greek minority has not been included in the minority groups whose rights have been curtailed since Turkey's reform process has been reversed. To do that, it engages with overlapping models of social diversity which have been suggested since the early 2000s as an answer to Turkey's burning minority rights questions. Improving the protection of minority rights of Turkey's Greek minority became first possible in the context of Turkey's EU membership-driven reform process between 1999 and 2010. While Turkey's EU membership hopes faded, the liberalization wave receded and a democratic backsliding became discernible in the early 2010s, the state of Turkey's Greek minority did not sharply deteriorate, as in the case of the Alevis or the Kurds. This was due to the rise of a communitarian understanding of human rights and a normative discourse celebrating diversity along the lines of the Ottoman millet system. Turkey's Greeks belonged to a minority group whose presence could be tolerated in a society organized not along liberal multiculturalism but along Ottoman millet-style, community-based diversity. A growing Ottoman nostalgia and Turkey's ambition to serve as a model in the region have become obstacles to a deterioration in the state of the Greek minority. This did not mean, however, that the government would go as far as to solve the remaining outstanding issues, challenge Turkish nationalist stereotypes or overcome negative reciprocity in minority rights when it came to Greek-Turkish relations. This became clearer in 2015, following the alliance of the incumbent Justice and Development Party (Adalet ve Kalkınma Partisi - AKP) with the far-right Nationalist Action Party (Milliyetçi Hareket Partisi - MHP), which had momentous consequences for the treatment of the Kurdish and Alevi minorities. Moreover, viewing minority rights as privileges awarded by the state - or the head of the executive (reis) - and not as emanating from the constitution and the rule of law coincided with a weakening of the autonomy of state institutions and the rise of a personalistic style of government with Recep Tayyip Erdoğan at the helm. This article concludes with an overview of the survival prospects of the minority in a Turkey which is trying 
to find its pace between full integration with Western and European institutions, Ottoman nostalgia and a solitary, illiberal path.

\section{From Atatürk to Erdoğan}

The emergence of Turkey's Greek minority coincided with the end of the Greek-Turkish 1919-1922 war. ${ }^{1}$ Following the August 1922 defeat of the Greek armed forces in Anatolia and the Armistice of Mudanya on 11 October 1923, approximately 1.5 million Ottoman Greeks were expelled from Western Anatolia and Eastern Thrace. Their legal status was sealed some weeks later. According to Articles 1 and 2 of the Greek-Turkish mandatory population agreement of 30 January 1923,

Article 1

As from the $1^{\text {st }}$ May 1923, there shall take place a compulsory exchange of Turkish nationals of the Greek Orthodox religion established in Turkish territory, and of Greek nationals of the Moslem religion established in Greek territory.

These persons shall not return to live in Turkey or Greece respectively without the authorization of the Turkish Government or of the Greek Government respectively.

Article 2

The following persons shall not be included in the exchange provided for in Article 1:

a. The Greek inhabitants of Constantinople.

b. The Moslem inhabitants of Western Thrace.

All Greeks who were already established before the $30^{\text {th }}$ October 1918, within the areas under the Prefecture of the City of Constantinople, as defined by the law of 1912, shall be considered as Greek inhabitants of Constantinople.

Moslems established in the region to the east of the frontier line laid down in 1913 by the Treaty of Bucharest shall be considered as Moslem inhabitants of Western Thrace. ${ }^{2}$

While Greece and Turkey agreed on the mandatory exchange of their minority populations, the Greeks of Istanbul became exempted. ${ }^{3}$ This clear statement did not prevent complications. The definition of 'Greek inhabitants of Constantinople' according to Article 2 led to considerable controversy. Thousands of Istanbul Greeks who failed to meet the treaty's residence definition, i.e. they were not established before 30 October 1918, the day the Armistice of Moudros was signed, within the areas under the Prefecture of the City of Constantinople, as defined by the law of 1912, were forced to leave Turkey. ${ }^{4}$ Others who met that definition preferred to emigrate to Greece, Western Europe or America before or after the signature of the population exchange agreement. Having identified with Greek irrendentism, they feared for their fate following the end of the Entente administration of Istanbul, the departure of Sultan Mehmet VI Vahdettin and the takeover of the city by Kemalist forces in October 1922. As a result, from a population of approximately 350,000 in 1912 , only about 125,000 Greeks remained in Istanbul, following the Lausanne agreements, and became citizens of republican Turkey. ${ }^{5}$ Istanbul Greeks would soon later be joined by the population of two Aegean islands, Imbros (İmroz, later renamed as Gökçeada) and Tenedos (Bozcaada), ${ }^{6}$ which were ceded to Turkey according to Article 14 of the Treaty of Lausanne. The same Article provided for a special administrative status for these islands. According to the 1928 Turkish census, there were 6,762 residents in Imbros and 1,631 residents in Tenedos, a sharp decline compared to pre-war figures showing 9,207 residents in Imbros and 6,620 in Tenedos and underscoring the extent of emigration to Greece and other overseas destinations. ${ }^{7}$

Being one of Turkey's officially recognized non-Muslim minorities, the Greek minority has faced discrimination throughout republican Turkish history. ${ }^{8}$ Despite the generous protective 
provisions of the Lausanne Treaty, republican Turkey proved rather inhospitable for its non-Muslim minorities. ${ }^{9}$ Armenians, Greeks and Jews suffered pressure on multiple levels. A series of anti-minority legislation in the interwar years, reminiscent of policies followed by the Young Turk administration during the First World War, aimed to reduce the influence of minorities in the economic, social and cultural life of Istanbul. ${ }^{10}$ These policies reached an apex with the 1942 Property Tax. This was a measure supposed to curb Second World War profiteering, but in fact, targeted Istanbul's non-Muslim citizens who were not involved in any illicit activity. It dealt a heavy blow, in particular against the minorities' middle class. Non-Muslim entrepreneurs and white-collar workers had to liquidate their assets at fire-sale prices to pay the exorbitant tax or face deportation to a labour camp at Aşkale, near Erzurum, eastern Turkey. ${ }^{11}$

The Greek minority faced additional pressures, as the outbreak of the Cyprus problem led to a rapid deterioration of Greek-Turkish relations in the mid-1950s. The 6-7 September 1955 pogrom against Istanbul's Greek minority broke out as the culmination of an anti-Greek minority campaign of mainstream Turkish print media, on the pretext of a bomb attack against the Turkish General Consulate in Thessaloniki, hosted in the house of Kemal Atatürk. ${ }^{12}$ Turkey's Greek minority became a hostage of the escalation of the Cyprus question and Greek-Turkish relations. This facilitated the implementation of outstanding plans for the decimation of Turkey's non-Muslim minorities. ${ }^{13}$ Following the outbreak of intercommunal conflict in Cyprus, Turkey denounced in March 1964 the 1930 Convention on Establishment, Commerce, and Navigation, which regulated the status of the members of Istanbul's Greek minority who held Greek citizenship and expelled approximately 12,000 Greek citizens. This caused the emigration of additional 20,000 minority members who held Turkish citizenship in 1964. The Cyprus problem served as an opportunity for re-inscribing Turkish national identity by scapegoating and oppressing Turkey's Greek minority. ${ }^{14}$ The subsequent confiscation of arable land and the establishment of an open-air prison in Gökçeada, the 1971 closure of the Heybeliada (Halki) Seminary were further milestones in the marginalization of Turkey's Greek minority. ${ }^{15}$ Minority members could not claim their constitutional rights as citizens of Turkey. The concept of 'local foreigner' (yerli yabancl) or 'guest citizen' (misafir vatandaş) entertained even by high court decisions pointed at the incompatibility between full citizenship rights and being a non-Muslim minority member in Turkey. ${ }^{16}$ Non-Muslims had to concede to a second-class citizen status and to the curtailment of their fundamental rights and freedoms. Moreover, negative reciprocity led to additional retaliatory measures against Turkey's Greek minority: anti-minority actions in Greece were perceived as giving Turkey the right to retaliate by targeting its Greek minority, paving the way to a 'race to the bottom.' ${ }^{17}$ Through a constant emigration wave, ${ }^{18}$ Turkey's Greek minority shrank in the late 1990 s to a point where its very viability came into question. ${ }^{19}$

New hopes emerged in December 1999, as Turkey became a candidate state for EU membership, following the European Council's decision in Helsinki. ${ }^{20}$ For the start of accession negotiations, Turkey had to meet the 'Copenhagen Criteria', and these included full respect for the rule of law and minority rights. Significant improvements were noted, as the EU-supported reform transformed the Turkish constitution, legislation and state institutions from 1999 to 2010. The verdicts of the European Court of Human Rights (ECtHR) also proved very helpful in promoting Greek minority rights. ${ }^{21}$ These benefitted not only the three non-Muslim minorities officially recognized by the Treaty of Lausanne, Armenians, Greeks and Jews, but also the Kurdish, the Alevi and other minorities. With reference to Turkey's Greek minority, while respect for the rule of law and minority rights increased, the position of the Ecumenical Patriarchate significantly improved. The number of official contacts between the Ecumenical Patriarchate and state authorities increased. While the requirement that the Ecumenical Patriarch be a Turkish citizen was not lifted, Turkish passports were given to high- and low-level clergy of the Ecumenical Patriarchate. ${ }^{22}$ Moreover, minority pious foundations (vakıf) and their properties were partially restored. ${ }^{23}$ Other important issues, such the reopening of the Heybeliada (Halki) Religious Seminary, the full restoration of church and school buildings and pious foundations, especially 
those controlled by the Papa Eftim family, remained unresolved. Some positive steps could also be noted outside Istanbul, such as the reopening of minority schools in Gökçeada (Imbros) for the first time in decades. As the reform process abated and Turkey's democratization and liberalization were reversed, affecting the rights of citizens and minority groups such as the Kurds and the Alevis, the Greek minority - alongside the Armenian and Jewish minorities - did not experience any significant backsliding, as far as the recent improvements were concerned. ${ }^{24}$

\section{Between republican citizenship and the Ottoman millet}

There is a discrepancy between Turkey's democratic backsliding since 2010 and the lack of any significant deterioration regarding the rights of Turkey's Greek minority. To understand this, one needs to explore the normative basis of minority rights in the Ottoman and republican Turkish context. The rights of Ottoman Greeks ${ }^{25}$ were prescribed by what came to be called the millet system, ${ }^{26}$ a system of non-territorial autonomy recognizing cultural, organizational and legal privileges to religious communities. ${ }^{27}$ The Ottoman Empire was not alone in its effort to address high religious and cultural diversity. ${ }^{28}$ While the Tanzimat reform aimed in the nineteenth century to weaken the primordial links of communities and establish an Ottoman citizenship, it met with limited success. Following the demise of the Ottoman Empire, the special status of the three minorities that were officially recognized in republican Turkey, the Armenian, the Greek and the Jewish, was all but rescinded. On the one hand, Article 42 of the Treaty of Lausanne had stated:

The Turkish Government undertakes to take, as regards non-Moslem minorities, in so far as concerns their family law or personal status, measures permitting the settlement of these questions in accordance with the customs of those minorities.

These measures will be elaborated by special Commissions composed of representatives of the Turkish Government and of representatives of each of the minorities concerned in equal number. In case of divergence, the Turkish Government and the Council of the League of Nations will appoint in agreement an umpire chosen from amongst European lawyers.

The Turkish Government undertakes to grant full protection to the churches, synagogues, cemeteries, and other religious establishments of the above-mentioned minorities. All facilities and authorisation will be granted to the pious foundations, and to the religious and charitable institutions of the said minorities at present existing in Turkey, and the Turkish Government will not refuse, for the formation of new religious and charitable institutions, any of the necessary facilities which are guaranteed to other private institutions of that nature..$^{29}$

On the other hand, there was intense state pressure to cancel any legal prerogatives of the non-Muslim minorities. During the preparations for the introduction of the 17 February 1926 new Turkish civil code, based on the Swiss model, the special minority commissions, representing the Armenian, Greek and Jewish minorities, were forced in autumn 1925 to declare that they renounced the special rights provided to them by Article 42. By doing so, the non-Muslim minorities pledged their confidence that as citizens of republican Turkey, they would enjoy all the rights that the new Turkish civil code and the Turkish constitution guaranteed. ${ }^{30}$ Nevertheless, non-Muslim minorities faced persistent discrimination throughout the republican era, and the transition from millet to minority membership in practice meant second-class citizen status. ${ }^{31}$ This was challenged with the political reform process, which reshaped Turkey's public sphere from December 1999 when Turkey was named a candidate state for EU membership. The rights of Turkey's recognized non-Muslim minorities, but also those of the Kurds, the Alevis and other minority groups sharply improved as a result of constitutional and legislative reforms aiming to enhance respect for human rights of all Turkish citizens and bridge the gap between majority and minority members. While this liberalization wave reached its limits at the end of the 2000s 
and the state of human rights in Turkey started deteriorating at an accelerating pace from 2010, the state of Turkey's Greek minority did not face any significant deterioration.

This seeming paradox can be best understood through the emergence of an alternative to a Europeanization normative framework that sustained the protection of Turkey's non-Muslim minorities in contrast to the others. Safeguarding positive steps in defence of the rights of Turkey's Greek minority became possible not in the context of Turkey's declining democratization process, but rather through the rising popularity of an alternative normative discourse and a communitarian understanding of human rights claiming to celebrate diversity inspired by the Ottoman millet system. Recognition of equal rights to all citizens of the Republic of Turkey regardless of religious or ethnic affiliation was put aside in favour of a revival of religious communities' rights, as they were prescribed in the Ottoman years. This resonated with Turkey's growing regional ambitions in the Balkans and the Middle East, which were underwritten by a novel approach towards its Ottoman legacy and the promotion of an Ottoman Islamist identity. ${ }^{32}$ Heavily influenced by the thought of Ahmet Davutoğlu, an academic who had authored a lengthy treatise on Turkey's 'strategic depth'33 and the crucial role of its Ottoman identity in that respect, the Erdoğan administration saw the 2011 Arab uprisings as a rare opportunity to expand its influence in the Middle East, reclaim leadership in a region long neglected by Turkish diplomacy and emerge as a global actor. As war was ravaging Libya, Iraq, Syria and Yemen and the fate of religious and cultural diversity appeared bleak, particularly in the territories controlled by the 'Islamic State', the Ottoman millet system was presented as a wise, local way of addressing religious and cultural diversity. Davutoğlu's rise to the post of the chief advisor of Prime Minister Erdoğan and then to that of Prime Minister reflected the increasing appeal of these ideas within the top echelons of Turkish government. Under these circumstances, sparing the reform steps referring to the Greek minority became possible through reference to the Ottoman Empire and its alleged tolerance towards diversity. Unlike the Alevis or the Kurds, the rights of non-Muslim minorities could remain respected, as this could resonate well with the Ottoman tradition of dhimmi, ${ }^{34}$ in a normative framework not inspired by liberal multiculturalism, but by a 'local,' Ottoman millet-style, community-based diversity. Turkey could champion its 'own,' 'local and national' (yerli ve millî) model of religious toleration to other Middle Eastern countries without any reference to Western values. Turkey's Ottoman nostalgia and its ambition to serve as a model in the region have both provided strong reasons not to weaken Greek -and other non-Muslim-minority rights. The symbolic value of such a policy did not cause any security concerns, given that the demographic decline of all three non-Muslim minorities, in particular the Greek, had already rendered them a tiny fraction of Turkey's population.

Within the millet framework, Alevis and seculars could not expect a more flexible approach vis-à-vis their grievances, as they could not fit within an Ottoman-inspired model of social and religious pluralism. The Ottoman Empire recognized Abrahamic religions but showed no tolerance to atheism or syncretic beliefs that could be framed as heresies by the religious mainstream. While Ottoman Kurds were never considered as a separate millet, accommodating their demands for recognition could be possible through a grand bargain between the Turkish state and some tribal chieftains. The decline of the primordial organization of Turkey's Kurdish populations and the rise of pro-Kurdish political parties and civil society focusing on individual rights and freedoms was something that a millet-inspired effort to promote diversity was not well equipped to address. ${ }^{35}$ The rise and fall of the 'Kurdish', or 'Democratic Opening', ${ }^{36}$ pointed to the fact that recognizing the rights of Turkey's largest minority remained politically non-expedient under any normative framework, while it was still unclear whether proposed reforms could meet the expectations of an increasingly ambitious and assertive Kurdish minority. This was linked to the U-turn of AKP policy regarding the Kurdish issue in summer 2015, its electoral partnership and increasing political alignment with the far-right Nationalist Action Party (Milliyetçi Hareket Partisi - MHP), its increasing identification with its junior partner's ideology and attitude towards minorities. This alignment precluded any possibility 
of challenging Turkish nationalist stereotypes or overcoming negative reciprocity in minority rights.

\section{Developments in the AKP era}

A seminal conference was organized in July 2006, almost four years after the rise of the AKP administration to power, with the aim of tracing the present and seek the future of Turkey's Greek minority. Fifty-one years after the 6-7 September 1955 pogrom that heralded the decline of Turkey's Greek minority, this conference raised some of the most critical questions about the past, present and future of the minority and became a reference point for future activities. While the Greek minority had reached a demographic low point, Turkey's political and economic conditions offered reasons for optimism. Turkey implemented a political and economic reform process, which benefited minorities. Turkey's Greeks aspired to find a voice under the changing circumstances and reclaim their position not only in the country's history, but also in its present and future. ${ }^{37}$

In its first two terms, the AKP administration appeared willing to undo some of the past injustices and restore some of the rights of non-Muslim minorities. For some years, a more inclusive definition of Turkish national identity was promoted, which allowed for religious and ethnic diversity, as establishing Turkishness upon civic grounds was discussed. ${ }^{38}$ It was commonly accepted that the status of the Greek minority improved during the early AKP years. ${ }^{39}$ Most importantly, as Turkey's democratization process lost steam and democratic backsliding prevailed in the third term of the AKP administration, Turkey's Greek minority did not experience a deterioration of its status and limitation of its rights. This could be understood if one considered the 'New Turkey' (Yeni Türkiye) social vision of the AKP administration. Non-Muslims were more compatible to the AKP vision than Kurds or Alevis, who challenged the success of Turkish nation-building within the majority population, or atheists or secularists, who claimed their right to live a secular lifestyle in Turkey and participate in the Turkish public sphere. Societal pressure (mahalle baskısı) was applied to those who went against the Sunni mainstream as expressed by government-affiliated religious orders (tarikats) and other religious organizations. ${ }^{40}$ In contrast to that, Christian or Jewish traditions were not seen as obstacles to a vision of Turkey as a plural but not necessarily liberal society, as long as they remained marginal and concerning a minuscule part of the population. Individual autonomy was not cherished in that context, although the communal rights of non-Muslim minorities were meant to be recognized and protected. Much as in the Ottoman years, the rights of individuals within their respective communities and the ability of interaction across community limits were both limited.

Both the minority representatives and the Ecumenical Patriarchate avoided any public statements or activities that could be interpreted as anti-government. This was a practice cherished throughout the republican era. On the other hand, the position of the Greek minority remained particularly vulnerable, as all improvements in terms of respect for human and minority rights remained reversible. While conspiracy theories about the ambitions of the Ecumenical Patriarchate to establish a second Vatican in the old city of Istanbul and the role of the Greek minority as a 'fifth column' survived in the far-right press, these were not treated with the same seriousness as before by mainstream media. ${ }^{41}$ Even the revival of the 'Sèvres syndrome', the irrational fear that foreign powers would use Turkey's minorities as an instrument to achieve its partition, according to the model of the abortive 1920 Treaty of Sèvres, was no more primarily projected upon Turkey's Greek minority and the Ecumenical Patriarchate but on Turkey's Kurdish minority. ${ }^{42}$ Anti-minority stereotypes and phobic reactions were targeting Turkey's Kurds. These reflected the changing demographic dynamics of non-Muslim and Kurdish minorities. As the Greek minority shrank and became demographically and 
economically insignificant, it ceased to fuel fear: Turkey's Kurdish population was becoming the new 'enemy within', substituting Turkey's non-Muslim minorities in the public imagery. Yet, the demographic insignificance of the Greek minority could be considered only a permissive condition and not a reason for its better treatment in comparison with the Kurdish or the Alevi minority.

The relative improvement of the position of the Greek minority was also due to developments in bilateral relations and the Cyprus conflict, as the minority has historically been held hostage to them. The Greek-Turkish rapprochement relaxed pressures on the Greek minority and allowed for a new approach to its rights. While disputes were not resolved, they did not prevent increased cooperation on the civil society level and stronger economic relations. The relegation of the significance of Greek-Turkish disputes and the Cyprus question in Turkish foreign policy and public discourse also reduced their negative effect on Turkey's Greek minority. Turkish foreign policy was increasingly focusing on the Middle East, Asia and Africa. Even the Cyprus question whose rise was one of the critical factors for the decline of Turkey's Greek minority and remained a crucial thorn in Greek-Turkish relations, ${ }^{43}$ failed to galvanize Turkish public opinion, following the Greek Cypriot rejection of the Annan Plan for the resolution of the Cyprus problem in the April 2004 referendum.

Meanwhile, the Turkish economic boom and the Greek financial woes between 2008 and 2015 facilitated the emigration of a sizeable number of Greek white-collar employees to Istanbul. Hundreds of first- or second-generation Istanbul Greeks were also considering a return to Istanbul. Reclaiming their Turkish citizenship became possible, and the improvement in relations provided new business opportunities. ${ }^{44}$ Tourism between the two countries boomed, as hundreds of thousands of Greeks and Turks were visiting Turkey and Greece respectively each year. ${ }^{45}$ In December 2013, during his visit to Athens, Prime Minister Ahmet Davutoğlu met with representatives of Athens-based associations of Istanbul and Gökçeada Greeks. Athens-based minority members had for the first time the chance to converse with a Turkish Prime Minister. Davutoğlu extended an invitation to Istanbul, Gökçeada and Bozcaada Greeks to return to their ancestral lands and listed the improvements in the status of the minority achieved under the AKP Administration. On their side, the Greek minority association leaders raised a list of issues concerning Turkey's Greek minority, those resident in Turkey and those expatriated. This meeting was a radical departure from decades-long policies of alienating emigrated members of the minority. ${ }^{46}$

Such developments also helped distract attention from Turkey's democratic backsliding and the severe deterioration of Turkey's human rights record, also regarding Kurdish and Alevi rights. In light of this, a decision of the General Directorate of Pious Foundations (Vakıflar Genel Müdürlügü) to have fifteen churches and synagogues in Istanbul and various other cities restored, served as a powerful public relations opportunity. Among the churches included in the programme was the St. Stephen Bulgarian Orthodox Church at Phanar (Fener), on the shores of Istanbul's Golden Horn and thirteen additional monuments belonging to the Jewish and various Christian communities, Armenian, Assyrian and Greek Orthodox: The Great Synagogue of Edirne, the Agios Nikolaos and Agia Marina Greek Orthodox Churches of Gökçeada (Imbros), the Assyrian Catholic and Greek Catholic Churches of Iskenderun, the Greek Orthodox St. John (Mar Yohanna) Church at Arsuz, near Iskenderun, the Armenian Protestant and Armenian Catholic Churches of the old town of Diyarbakir, the Fevkani Church in Nizip, the Synagogue in Antep, the Greek Orthodox Taxiarchis Church at Cunda, near Ayvalık, the Greek Orthodox St. George Church at Edirnekapı, Istanbul and the Greek Orthodox Church at Yayladağı, south of Antakya. ${ }^{47}$ Similar to the Edirnekapı Agios Georgios Church, St. Stephen Church was restored with funds of the Istanbul municipality. The January 2018 re-inauguration ceremony of the church, a few weeks after the reopening of the Edirnekapı Agios Georgios Church, was attended by no other than President Recep Tayyip Erdoğan, Prime Minister Binali Yıldırım and the Prime Minister of Bulgaria Boyko Borisov. In his ceremony speech, Erdoğan argued that: 
Throughout history, our forefathers (ecdad) took under their protection in the lands they conquered religious freedom and places of worship. They always protected them with the understanding 'you can live your religion; you are free to conduct your religious rites and you are under our protection'.... In this city [lstanbul] and in every corner of our ancient country, every monument has a special place in our heart. There are mosques, there are churches, there are synagogues; all of them stand together not only in Istanbul, but in various locations of our country. ${ }^{48}$

In his talk, Prime Minister Binali Yıldırım argued that 'with a recent law pious foundation assets were returned to the foundations' and added:

Thus, a total of 1029 assets belonging to 167 minority pious foundations were transferred to the pious foundations, and a major problem coming from the past has been resolved. ${ }^{49}$

While these figures were accurate, it was concealed that these measures amounted to only partial restitution: numerous pious foundations and their assets remained under state control..$^{50}$ By renovating non-Muslim places of worship not by reference to the Copenhagen Criteria or the Turkish constitution but to the Ottoman patrimony, the Turkish government framed at the highest level the relationship between the Turkish state and the Greek minority along the lines of the Ottoman millet tradition. It also attempted - with limited success - to deflect attention from mounting international accusations about the state of human and minority rights in Turkey.

\section{The minority pious foundations (vakıf)}

The number of Greek minority pious foundations was commensurate with the former demographic and economic strength of the Greek minority. In the early republican years, there were ninety-six Greek, fifty-eight Armenian and forty-two Jewish minority foundations. ${ }^{51}$ As the demographic decline of the minority was complicating the smooth operation of the foundations, their ability to perform activities fundamental for their operation was limited by legal and administrative means. Through a 1974 decision of the General Civil Council of the Turkish Court of Cassations (Yargitay), which considered a written declaration (beyanname) of immovable properties requested by the Turkish authorities and submitted by the pious foundations in 1936 to be their bylaws, pious foundations were deemed unable to acquire additional property after $1936 .^{52}$ Therefore, all subsequent property acquisitions were considered null and void, and immovable assets became subject to state confiscation. ${ }^{53}$ Besides, numerous foundations whose membership and operations had decreased because of the demographic decline of the Greek minority were taken over by the state..$^{54}$ The General Directorate of Foundations (Vakıflar Genel Müdürlüğ̈̈) assumed their administration and assets. Iconic buildings such as the Büyükada Orphanage (Büyükada Rum Yetimhanesi) and the Central Girls' High School (Merkez Rum Kız Lisesi) came under the control of the Turkish state.

Moreover, holding elections for the governing boards of the foundations, a crucial procedure for their legitimacy, became impossible. The lack of elections meant that several foundations failed to have any governing boards, as their members passed away or emigrated. In others, particularly the well-endowed ones, transparency and accountability standards left much to be desired. ${ }^{55}$ The expropriation of pious foundation assets continued unabated, sometimes with suspicions raised about the complicity of some governing board members. Reclaiming the immovable assets that had been confiscated was a critical task, which required the mobilization of all the forces of the scarce minority population. Establishing transparency and accountability was a formidable task.

Following the December 1999 European Council decision to nominate Turkey as an EU candidate, reform steps accelerated. Both the 1999-2002 coalition government under Bülent Ecevit and the AKP administration appeared willing to do away with some past injustices. This 
resonated with efforts to meet the Copenhagen criteria and raise the standards of minority rights protection. ${ }^{56}$ Through new legislation it became possible to lift some but not all obstacles that minority pious foundations met: it again became possible to acquire immovable property. Several foundations were released from state control and restored to their administrations, while elections took place in many but not all of the foundations..$^{57}$ It became possible for some foundations to appeal to the European Court of Human Rights (ECtHR) claiming the restitution of their properties confiscated following the 1974 decision of the Court of Cassations. ${ }^{58}$ Yet many problems remained unresolved. ${ }^{59}$ With a set of crucial verdicts, the ECtHR stated that Turkey had violated the European Convention of Human Rights (ECHR) and demanded the restitution of the confiscated assets to the foundations or their full and complete compensation. ${ }^{60}$ In August 2011, a new law on minority foundations allowed for reopening closed court cases and made it possible that some additional immovable assets could be recovered. Yet this did not mean that all problems were solved and all institutional obstacles were lifted. ${ }^{61}$ The recovery of some of the most iconic buildings to Greek pious foundations did not immediately bring about their restoration. The lack of available funds on the side of the Ecumenical Patriarchate and the minority foundations delayed the implementation of ambitious plans about some of the most prominent recovered buildings. The restoration of both the Büyükada Orphanage (Büyükada Rum Yetimhanesi) (Figure 1) and the Central Girls' High School (Merkez Rum KIz Lisesi) remained pending, due to the lack of the rather sizeable necessary funds. ${ }^{62}$ It was hoped that donors from Greece and the Greek diaspora would be willing to help raise funds needed for the renovation of the recovered buildings. Yet, the economic crisis of the 2010 s emerged as an additional obstacle to the realization of restoration plans.

In 2011, a new coordination scheme emerged for the better management of the foundations and the optimal allocation of the minority resources. The Association of Greek Foundations (Rum Vakıfları Derneği - RUMVADER) emerged as a solution for the problems that occurred because of demographic decline and poor governance in several pious foundations. ${ }^{63}$ Assisting the management of weakened pious foundations and improving transparency and accountability were welcomed as necessary steps for improving performance at a time the pious foundations were scrambling to identify and recover schools, churches, historic buildings and immovable assets confiscated over decades.

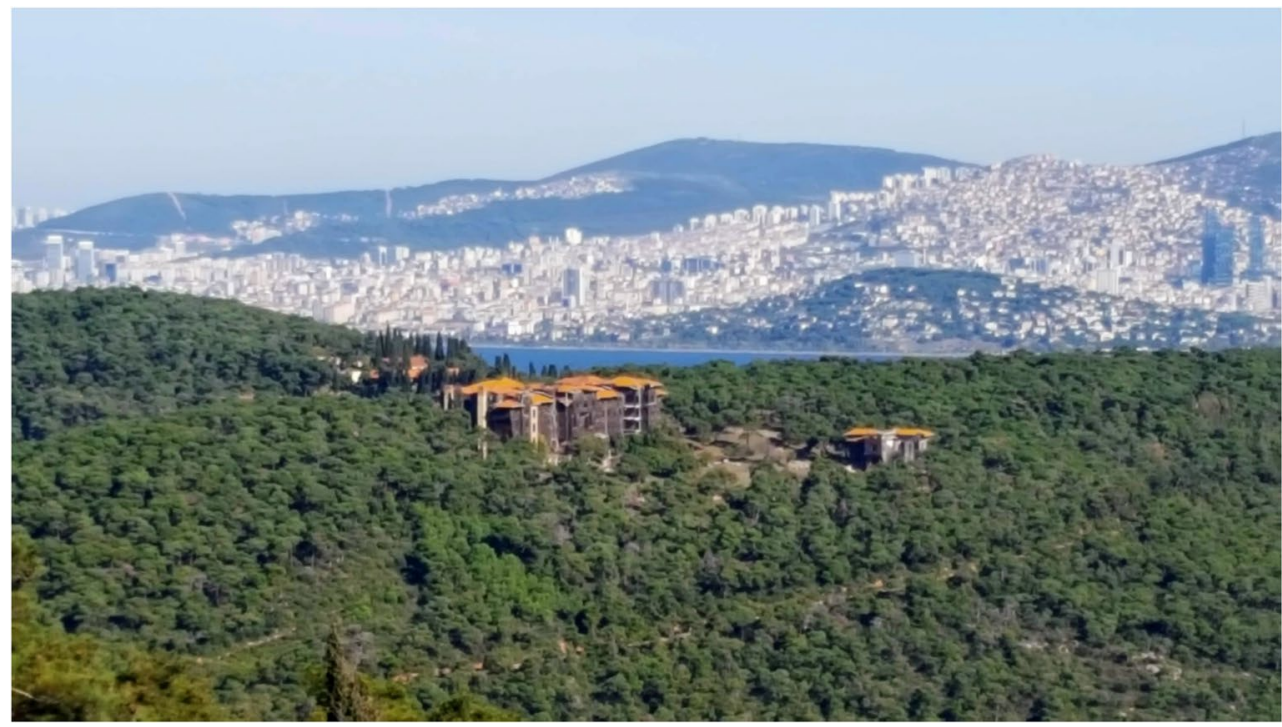

Figure 1. The Crumbling Greek Orphanage on the island of Büyükada, near Istanbul. Author photo. 
On the other hand, not all pious foundations were restituted to the Greek minority. One prominent example has been the Edirnekapı Agios Georgios Foundation which owns the church and the adjacent educational building in Istanbul. The Edirnekapı Agios Georgios Church was restored with funds of the Istanbul municipality under the aforementioned state project to restore fifteen non-Muslim places of worship. At the same time, its foundation remained under the administration of the General Directorate of Foundations (Vakıflar Genel Müdürlügü). In the November 2017 mass celebrating the restoration of the church, the representative of the General Directorate of Foundations claimed to be the host of the celebration. While the church complex remained accessible to priests and members of the Greek minority, the legal recovery of the foundation and its immovable assets remained pending. Such paradoxical situations could persist despite the aforementioned improvements in relations between the Greek minority and the Turkish state.

Last but not least, stands the restitution of a crucial part of minority history. The archives of numerous Greek minority associations and foundations have remained under state control, following their confiscation on different occasions during the twentieth century. A prominent example is the archive of the Constantinople Greek Literature Society (En Konstantinoupolei Ellinikos Filologikos Syllogos) ${ }^{64}$ Returning these archives to their rightful owners, i.e. Greek minority foundations, and making them publicly accessible would not only be rectifying an injustice to the minority. It could also shed light on some of the most interesting events of late Ottoman and republican Turkish history.

\section{The Papa Eftim affair}

The Papa Eftim affair, or the case of the 'Independent Turkish Orthodox Patriarchate' (Bağımsız Türk Ortodoks Patrikhanesi) is a prime example of how early-republican era attacks on the Greek minority have left their trace to date. The history of the institution is linked to Zeki Erenerol aka Papa Eftim. ${ }^{65}$ Papa Eftim was an Orthodox priest, born in Central Anatolia, who joined Turkish nationalist and Kemalist forces in the Greek-Turkish 1919-1922 war and attempted to take under his control the Ecumenical Patriarchate in the early years of republican Turkey. When this proved futile, he captured the Panagia Kafatiani church and other churches and pious foundations of the Istanbul borough of Karaköy (Galata). He then established the 'Independent Turkish Orthodox Patriarchate' (Bağımsız Türk Ortodoks Patrikhanesi), claiming to represent the Turkish-speaking Orthodox population of Istanbul. ${ }^{66}$ As the vast majority of the Turkish-speaking Orthodox remained loyal to the Ecumenical Patriarchate, Erenerol's organization eventually amounted to little more than a family business and an offshoot of the Turkish far-right. The Erenerol family managed Karaköy's churches, pious foundations and their assets. When Papa Eftim passed away, he was succeeded by his son Selçuk Erenerol, and following his passing, by his grandson Ümit Erenerol. Three churches in the Galata (Karaköy) district of Istanbul have remained under the Erenerol family's control. ${ }^{67}$ Without any clergy or flock, the Erenerol family has usurped some of the most important Orthodox heritage sites in Istanbul, which has comprised one of the most flagrant violations of Greek minority rights.

Ending this decade-long occupation and restoring the Karaköy churches, foundations and assets to their rightful owners has always been on the agenda of the Ecumenical Patriarchate and the Greek minority representatives. Nevertheless, despite repeated promises, Turkish authorities have abstained from taking any steps to remove the Erenerol family. The only significant restitution in the borough of Karaköy was that of the Karaköy Greek Vocational School (Astiki Scholi Galata), which was returned in 2012 and has become ever since a vibrant cultural centre. ${ }^{68}$

\section{Minority on the Aegean: Gökçeada (Imbros) and Bozcaada (Tenedos)}

The two Aegean islands of Gökçeada and Bozcaada, in Greek Imbros and Tenedos, were ceded to Turkey according to the Treaty of Lausanne, due to their strategic proximity to the Dardanelles. 
Special provisions were agreed upon for the protection of the local Greek population. According to Article 14:

The islands of Imbros and Tenedos, remaining under Turkish sovereignty, shall enjoy a special administrative organisation composed of local elements and furnishing every guarantee for the native non-Moslem population in so far as concerns local administration and the protection of persons and property. The maintenance of order will be assured therein by a police force recruited from amongst the local population by the local administration above provided for and placed under its orders.

The agreements which have been, or may be, concluded between Greece and Turkey relating to the exchange of the Greek and Turkish populations will not be applied to the inhabitants of the islands of Imbros and Tenedos. ${ }^{69}$

Despite the virtually autonomous status provided by the Article of the Treaty of Lausanne, the Greek minority on the two islands faced mounting discrimination. ${ }^{70}$ In 1927 the special administrative status of the two islands was lifted, and private Greek education was taken over by the Turkish state. Settlement policies and limitations to business activities and real estate transactions to minority members were introduced already in the 1940s. The outbreak of the Cold War, the rise of the Democrat Party to power in 1950, and Greece and Turkey's 1952 NATO membership led to an improvement in bilateral relations reflected in a brief interlude in assimilation policies. The outbreak of the Cyprus conflict in 1955 and the 6-7 September 1955 pogrom against Istanbul Greeks spelled terrible omens for the local minority population. ${ }^{71}$ In 1958 both islands were declared 'security zones', thus limiting crucial aspects of economic and social activity. In January 1964, at the height of another crisis in Cyprus, thirty local minority members were stripped of their Turkish citizenship, because of acts 'violating national security', while 300 others were warned to leave their professions which were reserved for ethnic Turks only according to

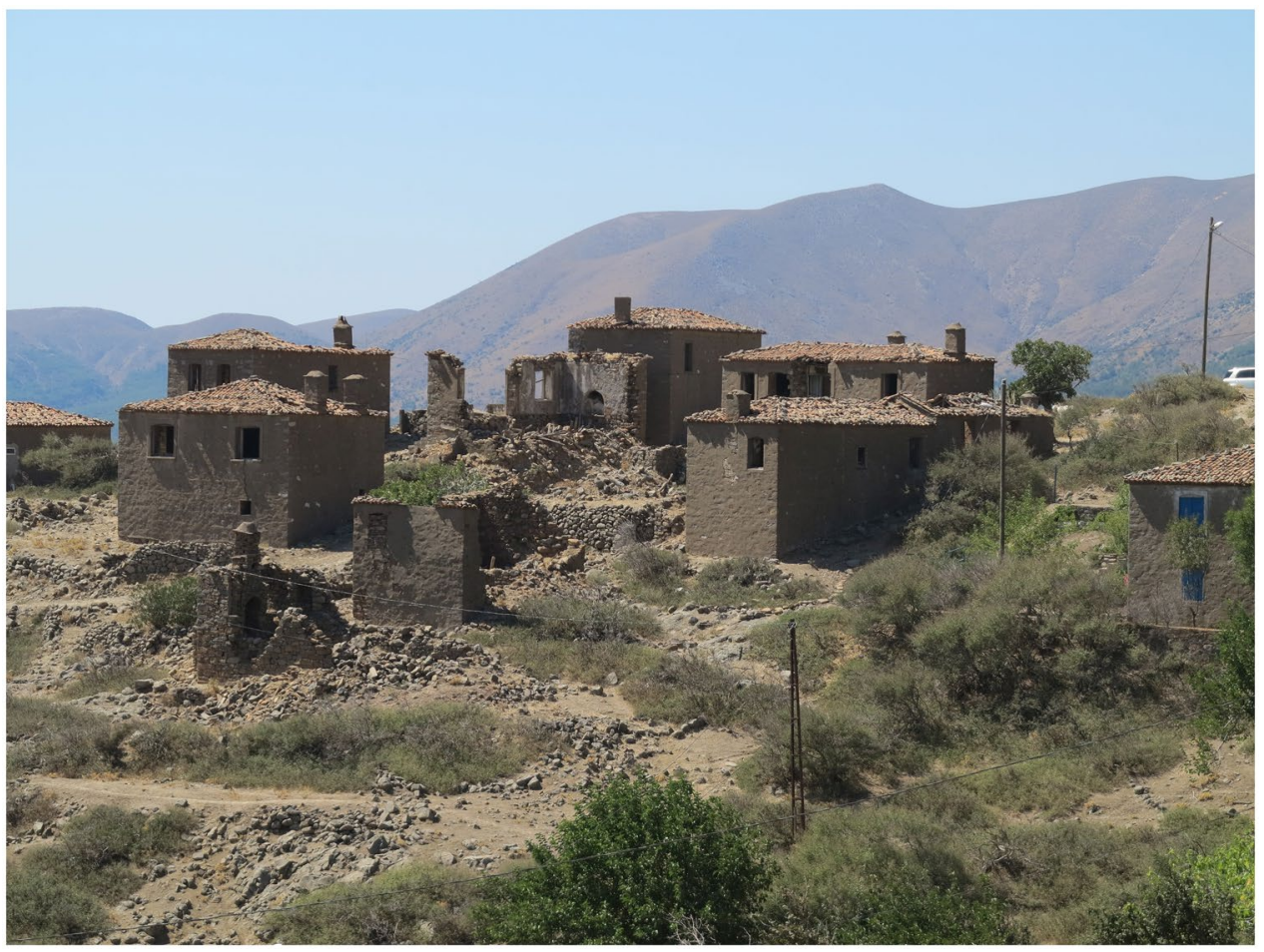

Figure 2. Ruined Houses at Dereköy (Schinoudi), Gökçeada (Imbros). Author photo. 
law. In March 1964, minority schools were closed once again, while minority members holding Greek citizenship were expelled. The purchase of land by minority Greeks was again prohibited, while minority-owned land became subject to extensive state expropriations. More than 90 per cent of the island's arable land was expropriated at meagre rates. An open prison was established in 1965 next to the biggest village of the island Schinoudi (Dereköy) (Figure 2). ${ }^{72}$ Prisoners and their families were settled on the island, which had a considerable impact on the local population's security, accelerating outmigration to Greece and other countries.

In 1970 the island's name was officially changed from İmroz to Gökçeada, and a new settlement project was introduced, bringing hundreds of Turkish inhabitants to the island. These conditions led to the decimation of the Greek minority population of both islands, who emigrated to Greece and other Western countries. In the late 1990s the Greek population of Gökçeada (Imbros) fell to approximately 400, while the Greek population of Bozcaada (Tenedos) dropped to about 20 persons. Greeks became a tiny minority on two islands where they used to be the only (in Gökçeada) and dominant (in Bozcaada) ethnic group when the Treaty of Lausanne was signed. ${ }^{73}$

Nevertheless, the state of the Greek minority on both islands started improving from the outset of the rapprochement in Greek-Turkish relations. Expatriate minority members and second-generation islanders embarked on visiting their ancestral islands in summer on a regular basis and renovating their houses. ${ }^{74}$ The Christian festival of the Dormition of Virgin Mary on 15 August became a focal point for the returnees. ${ }^{75}$ While in Bozcaada (Tenedos) no significant repatriation of its Greek population has been recorded, an increasing number of emigrated Greeks visit their island in the summer months. The situation is different on the island of Gökçeada (Imbros). A significant recovery of the island's Greek population has been recorded since the early 2000s. By 2015 approximately 200 first- or second-generation Imbriots resettled, over 100 more spent more than six months per year on the island while there were roughly 2000 to 3000 summer visitors. ${ }^{76}$ This coincided with the reopening of the island's Greek minority schools for the first time since the 1960s. ${ }^{77}$ A primary school opened in the village of Zeytinliköy (Agioi Theodoroi) and a high school in the village of Tepeköy (Agridia), permitting the settlement of families throughout the year. ${ }^{78}$

This small recovery of the minority population has been, however, based on rather flimsy grounds. The repatriation of Gökçeada (Imbros) Greeks enjoyed the financial support of the Greek state and private donors, and its sustainability remains questionable. While returnees were allowed to restore and renovate their old houses, the vast majority of the immovable assets confiscated in the 1960s and 1970s remained under state control or had already been allocated to ethnic Turkish citizens whose settlement on the island was sponsored by the state. As valuable arable, grazing and coastal land remained in the Turkish state's or settlers' hands, it remained difficult for repatriated Greeks to develop viable economic activities on the island and benefit from the rising tourism industry. This mitigated the optimism which the reopening of minority schools and the recovery of the minority population had brought about. ${ }^{79}$

\section{Conclusion}

The case of Turkey's Greek minority has helped elucidate the overlap and juxtaposition of different social diversity models in the AKP era. While republican Turkey's equal citizenship promise never materialized, the AKP government engaged in the first years of its term in an EU-induced liberalization reform aimed at improving human rights for all, including members of minority groups. When this process came to an end in the early 2010s and a reversal was even noticeable, the improvements in Turkey's Greek minority status were not undone. This was linked to the emergence of an alternative normative discourse celebrating diversity based on the Ottoman millet system. Unlike the Alevis and the Kurds, Turkey's Greeks were a minority that could be 
tolerated in a society organized not along liberal multiculturalism but along Ottoman millet-style, community-based diversity. This coincided with a decline in the autonomy and capacity of state institutions and the emergence of a personalistic style of government centred on Recep Tayyip Erdoğan. Turkey's Ottoman nostalgia and its ambition to serve as a model in the region have provided additional reasons for preventing a deterioration in the state of the Greek minority. This did not mean, however, particularly after 2015, that the government would go as far as to challenge Turkish nationalist stereotypes or overcome negative reciprocity in minority rights when it came to Greek-Turkish relations.

Nevertheless, despite the relative improvements of recent years, the state of Turkey's Greek minority has remained fragile. Its population size remains alarmingly small, and a shift in the fortunes of Turkey's politics is likely to push it closer to extinction. The future of Istanbul's Greek minority remains contingent upon Turkey's democratization process, as well as upon the active participation of minority members within Turkish civil society. Developing institutions that could guarantee the rule of law, human rights protection and liberal democracy in Turkey is probably the litmus test for the viability of Turkey's Greek minority. Ad hoc arrangements and recognition of privileges may have indeed proven vital for the recovery of part of the minority's immovable properties and rights or may have prevented worse developments against the minority. Yet they cannot provide a long-lasting solution. A liberal democratic Turkey remains the best guarantor for the survival and prosperity of the Greek minority and its institutions. The free operation of the minority pious foundations, the restitution of its confiscated churches, schools and other immovable assets in Karaköy and beyond can be supported through a demographic boost. This could occur as a combination not of the repatriation of a sizeable number of minority members who emigrated in the past and the settlement of expatriate Greeks without immediate family connections to Turkey. While in principle, the instrumentalization of human rights through reciprocity should come to an end, in the short term shifting the paradigm from negative to positive reciprocity could become a remedy for a set of problems that remained deadlocked for decades at the expense of minorities and bilateral relations. Addressing these could contribute to the revitalization of the minority.

Turkey's Greek minority is no more a significant economic and political stakeholder in Turkey. It maintains, however, a powerful symbolic role as living evidence and witness of Turkey's multicultural and multi-ethnic past. Turkey's reconciliation with its own history is a critical step in the process of the country's democratic consolidation. Shifting from a parochial, millet-based communitarian to a liberal individualist understanding of minority rights would constitute a crucial step. The Ecumenical Patriarchate, one of the world's oldest surviving institutions, stands as an excellent example of the Greek minority's heritage and soft power value. Custodians of an ancient culture that comprises a large piece of the mosaic of contemporary Turkey, Turkey's Greeks bridge the country not only to its past but also to its present and future.

\section{Disclosure statement}

No potential conflict of interest was reported by the author.

\section{Funding}

This work was supported by the KEAC-BSR H2020 Marie Skłodowska-Curie Action (H2020-MSCA-RISE-2016-734645).

\section{ORCID}

loannis N. Grigoriadis (iD) http://orcid.org/0000-0003-0882-6125 


\section{Notes}

1. For an early and classical study of the population exchange, see Stephen P. Ladas, The Exchange of Minorities: Bulgaria, Greece and Turkey (New York: The Macmillan Company, 1932).

2. Turkish Ministry of Foreign Affairs, Convention Concerning the Exchange of Greek and Turkish Populations Signed at Lausanne, January 30, 1923 (Republic of Turkey: Ankara, 1923), Available at http://www.mfa.gov. tr/lausanne-peace-treaty-vi_-convention-concerning-the-exchange-of-greek-and-turkish-populations-sign ed-at-lausanne_.en.mfa.

3. Istanbul Greeks were a few months later joined by the Greek residents of two Aegean islands of Imbros and Tenedos. Both were under Greek sovereignty on 30 January 1923 but were transferred to Turkey according to the Treaty of Lausanne of 24 July 1923.

4. Onur Yıldırım, Diplomacy and Displacement: Reconsidering the Turco-Greek Exchange of Populations, 1922-1934 (New York and London: Routledge, 2007), pp.161-3.

5. Alexis Alexandris, The Greek Minority in Istanbul and Greek-Turkish Relations 1918-1974 (Athens: Center for Asia Minor Studies, 1983).

6. The population of Imbros was exclusively Greek Orthodox, while in Tenedos Muslims amounted to about 20 per cent of the population. For more information, see Alexis Alexandris, 'Imbros and Tenedos: A Study of Turkish Attitudes toward Two Ethnic Greek Island Communities since 1923', Journal of the Hellenic Diaspora Vol.7, no.1 (1980).

7. Ibid., pp.6, 22.

8. Alexandris, The Greek Minority in Istanbul and Greek-Turkish Relations 1918-1974.

9. On the fate of two other non-Muslim minorities, that reached the brink of extinction, the Bulgarian and the Greek Catholic, see Elçin Macar, İstanbul'un Yok Olmuş Iki Cemaati: Doğu Ritli Katolik Rumlar ve Bulgarlar [Istanbul's Two Extinct Communities: Eastern Rite Catholic Greeks and Bulgarians] (Istanbul: İletişim, 2002).

10. Soner Çağaptay, 'Reconfiguring the Turkish Nation in the 1930s', Nationalism and Ethnic Politics Vol.8, no.2 (2002), loannis N. Grigoriadis, 'Europe Overshadowed: Reciprocity as a Race to the Bottom in Religious Freedom' in Othon Anastasakis, Kalypso Nicolaidis and Kerem Oktem (eds), Under the Long Shadows of Europe: Greeks and Turks in the Era of Post-Nationalism (Leiden: Brill, 2009), pp.171-7, Tanıl Bora, "'Ekalliyet Yılanları": Türk Milliyetçiliği ve Azınlıklar' ["'Minority Snakes": Turkish Nationalism and Minorities'] in Tanıl Bora (ed.), Milliyetçilik [Nationalism] (Istanbul: İletişim, 2002), pp.911-13, Banu Eligür, 'Ethnocultural Nationalism and Turkey's Non-Muslim Minorities During the Early Republican Period', British Journal of Middle Eastern Studies Vol.46, no.1 (2019), pp.172-6.

11. Ayhan Aktar, Varlık Vergisi ve 'Türkleştirme' Politikaları [The Property Tax and Policies of Turkification] (Istanbul: Illetişim, 2000), pp.196-200.

12. It was later proven that this attack was executed by the Turkish secret services in its aim to trigger public support for the 6-7 September 1955 pogrom. See Speros Vryonis Jr., The Mechanism of Catastrophe: The Turkish Pogrom of September 6-7, 1955, and the Destruction of the Greek Community of Istanbul (New York: Greekworks.com, 2005), pp.93-8.

13. For more information on the 6-7 September 1955 events, see Dilek Güven, Cumhuriyet Dönemi Azınlık Politikaları ve Stratejileri Bağlamında 6-7 Eylül Olayları [The 6-7 September Events in the Context of Republican Era Minority Policies and Strategies] (Istanbul: Illetişim, 2006), Vryonis Jr., The Mechanism of Catastrophe: The Turkish Pogrom of September 6-7, 1955, and the Destruction of the Greek Community of Istanbul.

14. Alper Kaliber, 'Re-Engaging the Self/Other Problematic in Post-Positivist International Relations: the 1964 Expulsion of Greeks from Istanbul Revisited', Southeast European and Black Sea Studies Vol.19, no.3 (2019), pp.374-80.

15. Alexandris, 'Imbros and Tenedos: A Study of Turkish Attitudes toward Two Ethnic Greek Island Communities since 1923', pp.26-8.

16. Baskın Oran, Türkiye'de Azınlıklar: Kavramlar, Lozan, lç̧ Mevzuat, lçctihat, Uygulama [Minorities in Turkey: Terms, Lausanne, Domestic Legislation, Jurisprudence, Implementation] (Istanbul: Türkiye Ekonomik ve Sosyal Etüdler Vakfı (TESEV) Yayınları, 2004), pp.74-83.

17. Grigoriadis, 'Europe Overshadowed: Reciprocity as a Race to the Bottom in Religious Freedom', pp.182-6. For a fruitful discussion of the concept of reciprocity in Greek-Turkish relations, see Samim Akgönül (ed.), Reciprocity: Greek and Turkish Minorities: Law, Religion and Politics (Istanbul: Istanbul Bilgi University Press, 2008).

18. Ahmet Içduygu, Şule Toktas and B. Ali Soner, 'The Politics of Population in a Nation-Building Process: Emigration of Non-Muslims from Turkey', Ethnic and Racial Studies Vol.31, no.2 (2008), pp.370-6.

19. Most of the expelled or emigrated Istanbul Greeks settled in Athens, particularly in its southern, sea-side suburbs, nourishing a distinct identity that distanced itself from mainstream Greek and Turkish national identities. On these dynamics, see llay Romain Ors, 'Beyond the Greek and Turkish Dichotomy: The Rum Polites of Istanbul and Athens', South European Society and Politics Vol.11, no.1 (2006), Hakan Yücel, Rum Olmak Rum Kalmak [Being Greek, Staying Greek] (Istanbul: İstos, 2018). 
20. On this see, Nora Fisher Onar and Meriç Özgüneş, 'How Deep a Transformation? Europeanization of Greek and Turkish Minority Policies', International Journal on Minority and Group Rights Vol.17, no.1 (2010), pp.129-34.

21. On this, also see an article authored by one of the leading figures of Turkey's Greek minority: Laki Vingas, 'From the Margins to the Center of Social Life: Non-Muslim Minorities in Modern Turkey', Turkish Policy Quarterly Vol.13, no.1 (2004).

22. Ayla Jean Yackley, Turkey Offers Citizenship to Orthodox Archbishops (Reuters: Istanbul, 2010), available at https://www.reuters.com/article/idINIndia-50289820100721 (posted on 21 July 2010).

23. For more information on this, see Dilek Kurban and Kezban Hatemi, Bir 'Yabancı'laştırma Hikâyesi: Türkiye'de Gayrimüslim Cemaatlerin Vakıf ve Taşınmaz Mülkiyet Sorunu [A Tale of 'Alienation': The Problem of Turkey's Non-Muslim Community Foundations and Immovable Property] (Istanbul: TESEV, 2009), Dilek Kurban and Konstantinos Tsitselikis, A Tale of Reciprocity: Minority Foundations in Greece and Turkey (Istanbul: TESEV, 2010). See also Sebnem Arsu, 'Turkish Government to Return Seized Property to Religious Minorities', New York Times, 28 Aug. 2011.

24. It is also worth noting that the status of Turkey's Greek minority was not affected by a deterioration in Turkey's relations with Greece in the early 2010s, in contrast with Turkey's relations with Armenia and Israel.

25. On this, see Richard Clogg, 'The Greek Millet in the Ottoman Empire' in Benjamin Braude and Bernard Lewis (eds), Christians and Jews in the Ottoman Empire: The Functioning of a Plural Society (New York: Holmes \& Meier, 1982).

26. Karen Barkey and George Gavrilis, 'The Ottoman Millet System: Non-Territorial Autonomy and Its Contemporary Legacy', Ethnopolitics Vol.15, no.1 (2016), pp.24-8.

27. On the controversial antiquity of the millet system, see the seminal Benjamin Braude, 'Foundation Myths of the Millet System' in Benjamin Braude and Bernard Lewis (eds), Christians and Jews in the Ottoman Empire: The Functioning of a Plural Society (New York: Holmes \& Meier, 1982).

28. Fikret Adanir, 'Religious Communities and Ethnic Groups under Imperial Sway: Ottoman and Habsburg Lands in Comparison' in Dirk Hoerder, Christiane Harzig, and Adrian Shubert (eds), The Historical Practice of Diversity: Transcultural Interactions from the Early Modern Mediterranean World to the Postcolonial World (New York: Berghahn Books, 2003).

29. Carnegie Endowment for International Peace, 'Treaty of Peace with Turkey Signed at Lausanne, July 24, 1923', The Treaties of Peace 1919-1923 (New York: Carnegie Endowment for International Peace, 1924).

30. Aktar, Varlık Vergisi ve 'Türkleştirme' Politikaları, pp.112-13. See also Alexandris, The Greek Minority in Istanbul and Greek-Turkish Relations 1918-1974, pp.135-8, Avram Galanti, Türkler ve Yahudiler: Tarihî, Siyasî Tetkik [Turks and Jews: A Historical, Political Study] (Istanbul: Gözlem, 1995), pp.61-6.

31. Barkey and Gavrilis, 'The Ottoman Millet System: Non-Territorial Autonomy and Its Contemporary Legacy', p.34.

32. On this, see Lisel Hintz, Identity Politics Inside Out: National Identity Contestation and Foreign Policy in Turkey (Oxford and New York: Oxford University Press, 2018), pp.101-26.

33. See Ahmet Davutoğlu, Stratejik Derinlik: Türkiye'nin Uluslararası Konumu [Strategic Depth: Turkey's International Position] (Istanbul: Küre, 2001).

34. Ioannis N. Grigoriadis, 'On the Europeanization of Minority Rights Protection' in Aylin Güney and Ali Tekin (eds), The Europeanization of Turkish Public Policies: A Scorecard (Abingdon and New York: Routledge, 2015), p.140

35. On the social and political foundations of the Kurdish question, see Martin Van Bruinessen, Agha, Shaikh, and State: the Social and Political Structures of Kurdistan (London: Zed Books, 1992), Gareth M. Winrow, The Kurdish Question and Turkey: An Example of a Trans-State Ethnic Conflict (Abingdon and New York: Routledge, 2013).

36. The 'Kurdish Opening' was an initiative of the AKP government launched in 2009, aiming to pave the ground for the resolution of Turkey's Kurdish question. The peace process collapsed in summer 2015, and clashes between the Turkish security forces and the PKK resumed.

37. For the minutes of the conference, see Zoğrafyon Lisesi Mezunları Derneği, İstanbul Rumları: Bugün ve Yarın [Istanbul Greeks: Today and Tomorrow] (Istanbul: İstos, 2012).

38. Ioannis N. Grigoriadis, 'Türk or Türkiyeli? The Reform of Turkey's Minority Legislation and the Rediscovery of Ottomanism', Middle Eastern Studies Vol.43, no.3 (2007), pp.428-35.

39. Vingas, 'From the Margins to the Center of Social Life: Non-Muslim Minorities in Modern Turkey', pp.116-17.

40. Adnan Çetin, 'Bir Kavramın Kısa Tarihi: "Mahalle Baskısı"' ['A Short History of a Term: "Neighbourhood Pressure"'], Mukaddime Vol.3, no.3 (2011), pp.85-90.

41. Bora, "'Ekalliyet Yılanları": Türk Milliyetçiliği ve Azınlıklar'.

42. Michelangelo Guida, 'The Sèvres Syndrome and "Komplo" Theories in the Islamist and Secular Press', Turkish Studies Vol.9, no.1 (2008), pp.38-9.

43. Ziya Öniş, 'Greek-Turkish Relations and the European Union: A Critical Perspective', Mediterranean Politics Vol.6, no.3 (2001), pp.40-2.

44. Orhan Kemal Cengiz, 'Are Greeks Returning to Turkey?', Al-Monitor, 20 May 2014. 
45. In 2015 approximately 740,000 Greek tourists visited, while approximately 1,150,000 Turkish tourists visited Greece. See İstanbul Ofisi, 'Hedef Bir Milyon Yunan Turist' ['Aim: One Million Greek Tourists'], Hürriyet, 18 July 2017.

46. Istanbul Desk, 'Turkey FM Davutoğlu's Historical Meeting with Imroz People in Athens', Hürriyet Daily News, 17 Dec. 2013.

47. Anadolu Haber Ajansı, Türkiye'deki 14 Kilise ve Sinagog Restore Edildi Edildi [14 Churches and Synagogues in Turkey were Restored] (Istanbul, 2017), available at https://www.aa.com.tr/tr/kultur-sanat/turkiyedeki-14-kilise-v e-sinagog-restore-edildi-/1013003.

48. Basın Merkezi, Restorasyonunu Tamamlanan Bulgar Kilisesi Ibadete Açıldı [Following the Completion of its Restoration, the Bulgarian Church was Opened for Service] (Istanbul: İstanbul Büyükşehir Belediye Başkanlığı, 2018), available at https://www.ibb.istanbul/News/Detail/34419.

49. İstanbul Ofisi, İstanbul'daki Demir Kilise Törenle Açıldı [The Iron Church in Istanbul was Opened with a Ceremony] (Deutsche Welle: Istanbul, 2018), available at https://www.dw.com/tr/istanbuldaki-demir-kilise-t\%C 3\%B6renle-a\%C3\%A7\%C4\%B1ld\%C4\%B1/a-42056192.

50. United States Department of State, 2019 Report on International Religious Freedom: Turkey (Washington DC: Office of International Religous Freedom, 2019).

51. Dilek Kurban and Konstantinos Tsitselikis, A Tale of Reciprocity: Minority Foundations in Greece and Turkey (Istanbul: TESEV, 2010), pp.30-7.

52. Mustafa Alkan, 'Azınlık Vakıfları (Tarihî Arkaplanı, Hukukî Yapısı ve lç Analizi)' ['Minority Foundations: Historical Background, Legal Structure and Internal Analysis'], Akademik Bakış Vol.2, no.4 (2009), p.101, Kurban and Tsitselikis, A Tale of Reciprocity: Minority Foundations in Greece and Turkey, pp.12-13.

53. Pınar Dinç Kenanoğlu, 'Discrimination and Silence: Minority Foundations in Turkey During the Cyprus Conflict of 1974', Nations and Nationalism Vol.18, no.2 (2012), pp.274-6.

54. Kurban and Hatemi, Bir 'Yabancı'laştırma Hikâyesi: Türkiye'de Gayrimüslim Cemaatlerin Vakıf ve Taşınmaz Mülkiyet Sorunu, pp.17-18.

55. Kurban and Tsitselikis, A Tale of Reciprocity: Minority Foundations in Greece and Turkey, pp.10-11.

56. On this, see Dilek Kurban, 'Türkiye'nin Azınlık Sorununun Anayasal Çözümü: Eşitlik Ile Yüzleş(me)mek' ['A Constitutional Solution of Turkey's Minority Problem: (Not) Coming to Terms with Equality'], Birikim, no.188 (2004).

57. Dilek Kurban, Vakıflar Kanunu Tasarısı'nın Cemaat Vakıflarını Ilgilendiren Hükümleri Üzerine [About the Provisions of the Foundations Law Draft Concerning the Community Foundations] (Istanbul: TESEV, 2004).

58. See, for example, European Court of Human Rights (ECtHR), Fener Rum Erkek Lisesi Vakfı vs. Turkey [no.34478/97] (Strasbourg: Former Second Section, 2007).

59. Dilek Kurban, Vakıflar Kanunu Tasarısı Gayrimüslim Cemaat Vakıflarının Sorunları Için Çözüm Getirmiyor [The Foundations Law Draft does not Bring a Solution for the Problems of Non-Muslim Community Foundations] (Istanbul: TESEV, 2007).

60. Grigoriadis, 'Europe Overshadowed: Reciprocity as a Race to the Bottom in Religious Freedom', p.176.

61. Laki Vingas, 'The Minority Foundations in Turkey and Their Role as Cultural Bridges', Paper presented at the Vienna-Istanbul 2010: Crossroads of Faiths and Cultures in Turkey (Austrian Consulate, Yeniköy, Istanbul, 12 Oct. 2010).

62. Istanbul Desk, 'Büyükada Greek Orthodox Orphanage, One of Europe's "Seven Most Threatened Heritage Sites'", Hürriyet Daily News, 18 Mar. 2018.

63. Mine Yildirim, 'The Return of Property to Community Foundations in Turkey: The Legislative Decree', European Yearbook of Minority Issues Online Vol.10, no.1 (2013), pp.590-4.

64. Elçin Macar, 'İstanbul'dan Ankara'ya: İstanbul Helen Edebiyat Cemiyeti (Syllogos) Kütüphanesi'nin İzinde' ['From Istanbul to Ankara: In Search for the Library of the Constantinople Greek Literature Society (Syllogos)'], Istanbul Ticaret Üniversitesi Sosyal Bilimler Dergisi Vol.12, no.23 (2013), pp.144-7.

65. Ioannis N. Grigoriadis, Instilling Religion in Greek and Turkish Nationalism: A 'Sacred Synthesis' (New York: Palgrave Macmillan, 2012), pp.38-42.

66. On the Papa Eftim affair, see also Foti Benlisoy and Stefo Benlisoy, Türk Milliyetçiliğinde Katedilmemiş Bir Yol: 'Hıristiyan Türkler've Papa Eftim [A Path not Traversed in Turkish Nationalism: "Christian Turks" and Papa Eftim] (Istanbul: İstos, 2016), Foti Benlisoy and Stefo Benlisoy, 'Türk Milliyetçiliğinde Katedilememiş Bir Yol: Hristiyan Türkler' ['A Path that could not be Traversed in Turkish Nationalism: Christian Turks'], Modern Türkiye'de Siyasî Düşünce Vol.4 (2008).

67. One of the churches under Erenerol's control, the Transfiguration (Metamorphosis tou Sotiros) church, was demolished in the 1950s during the razing of some Karaköy blocks by the Menderes administration. The St. Nicholas (Agios Nikolaos) church was destroyed by fire in 2002 and has remained in ruins ever since. Two churches, Virgin Mary of Caffa (Panagia Kafatiani) and St. John of Chians (Agios loannis ton Chion), still remain under the control of the Erenerol family and the 'Foundation of Independent Turkish Orthodox Churches Patriarchate' (Bağımsız Türk Ortodoks Kiliseleri Başpapazlığı Vakfı). 
68. News Desk, 'Galata Rum Okulu 23 Yıl Sonra lade Edildi', ['The Galata Greek Orthodox School was Returned

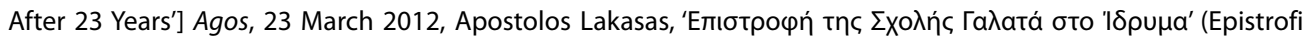

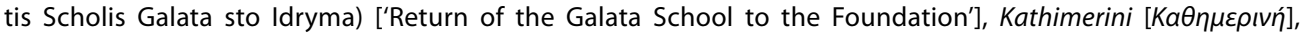
27 March 2012.

69. Carnegie Endowment for International Peace, 'Treaty of Peace with Turkey Signed at Lausanne, July 24, 1923'.

70. Alexandris, 'Imbros and Tenedos: A Study of Turkish Attitudes toward Two Ethnic Greek Island Communities since 1923', pp. 16-28, Giorgos Tsimouris, I $\mu \beta \rho$ ıo (Imvrioi) [Imbriots] (Athens: Da Vinci, 2013).

71. Yıldıray Oğur, 'Bir Itiraf: İmroz'u Nasıl Gökçeada Yaptık' ['A Confession: How we Turned İmroz to Gökçeada'] Taraf, 28 Oct. 2012.

72. Alanur Cavlin Bozbeyoglu and Işıl Onan, Changes in the Demographic Characteristics of Gokceada (Ankara: Hacettepe University Institute of Population of Studies, Ankara, 2000), p.3.

73. Ibid., pp.13-14.

74. Huw Halstead, Greeks without Greece: Homelands, Belonging, and Memory Amongst the Expatriated Greeks of Turkey (Abingdon and New York: Routledge, 2018), pp.217-25.

75. Elif Babül, 'Claiming a Place through Memories of Belonging: Politics of Recognition on the Island of Imbros', New Perspectives on Turkey Vol.34 (2006), pp.58-60, Giorgos Tsimouris, 'Pilgrimages to Gökçeada (Imvros), a Greco-Turkish Contested Place: Religious Tourism or a Way to Reclaim the Homeland?' in John Eade and Mario Katić (eds), Pilgrimage, Politics and Place-Making in Eastern Europe (Farnham and Burlington: Ashgate, 2016), pp.43-55, Giorgos Tsimouris, 'Reconstructing "Home" among the "Enemy": The Greeks of Gökseada (Imvros) after Lausanne', Balkanologie Vol.5, no.1-2 (2001), pp.6-12, Elif Babül, 'Home or Away?: On the Connotations of Homeland Imaginaries in Imbros' in Marie-Aude Baronian, Stephan Besser, and Yolande Jansen (eds), Diaspora and Memory: Figures of Displacement in Contemporary Literature, Art and Politics (Leiden: Brill Rodopi, 2006), pp.48-9.

76. Huw Halstead, "Native Tourists": Belonging and Alienation in the Greek Return to Imbros (Norwich: Refugee History, 2019), available at http://refugeehistory.org/blog/2019/2/20/native-tourists-belonging-and-alienation-i n-the-greek-return-to-imbros.

77. Kursat Akyol, 'For Turkey's Greek Minority, an Island School Provides Fresh Hope', Al-Monitor, 2 Oct. 2015.

78. News Desk, 'Families from Greece Return to Turkey's Gökçeada after Schools Open', Hürriyet Daily News, 19 Dec. 2016.

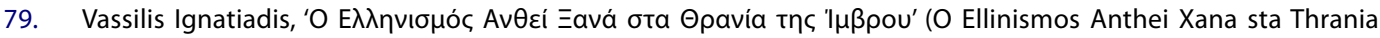
tis Imvrou) ['Hellenism Blooms Again at the School Desks of Imbros'], 'EOvo [Ethnos], 30 Sept. 2019. 